\title{
Impact of Stock Market Liquidity on Herding Behaviour: A Comparative Study of Conglomerate and Consumer Goods Sectors
}

\author{
Ifeoma Patricia Osamor ${ }^{1, *}$, Edwin C. Anene ${ }^{2}$, Qudus Ayotunde Saka ${ }^{1}$ \\ ${ }^{1}$ Department of Accounting, Faculty of Management Sciences, Lagos State University, Lagos State, Nigeria \\ ${ }^{2}$ Department of Management and Accounting, Faculty of Management Sciences, \\ Ladoke Akintola University of Technology, Oyo State, Nigeria \\ *Corresponding author: ifyposamor@gmail.com
}

Received March 04, 2019; Revised April 10, 2019; Accepted May 04, 2019

\begin{abstract}
Stock market investors are regarded as rational being, but during stock market liquidity, investors tend to exhibit herding behaviour. Several factors affect stock market liquidity, but the liquidity of Conglomerate and Consumer goods sectors may not be obvious. This study examined the impact of stock market liquidity on herding behaviour of investors in Nigerian stock market with focus on Conglomerate and Consumer goods sectors. Monthly data of stock returns and market capitalization for fifteen years from 2001 - 2015 were used and 28 companies' stocks from both sectors were considered. OLS model was used to determine the impact, existence and extent of herding behavior in these sectors. The results showed that stock market liquidity had impact on herding behaviour in both sectors and during high and low market liquidity, there is an evidence of herding behaviour which is not statistically significant in Conglomerate sector compared to Consumer goods sector. The study recommended that NSE should make information available to all market participants in order to boost their confidence in making their own decisions.
\end{abstract}

Keywords: herding behavior, stock market liquidity, Nigerian stock market, average monthly returns

Cite This Article: Ifeoma Patricia Osamor, Edwin C. Anene, and Qudus Ayotunde Saka, "Impact of Stock Market Liquidity on Herding Behaviour: A Comparative Study of Conglomerate and Consumer Goods Sectors." Journal of Finance and Accounting, vol. 7, no. 1 (2019): 6-11. doi: 10.12691/jfa-7-1-2.

\section{Introduction}

One of the factors that determine economic growth is efficiency of the stock market; therefore, the stock market can be regarded as the engine of economic growth. [1] defined the stock market as a hub where facilities are provided to the investors to purchase and sell their shares, bonds and debenture. In other words, stock market is a platform for trading various securities and derivatives without any barriers. According to [2], stock market was seen as a public market where company stocks and derivatives are traded at an agreed price; these are securities listed on a stock exchange and those privately traded.

In the stock market, investors are regarded as rational human being who make investment decisions based on risk and the associated returns from that investment. According to the 'Prospect Theory' of [3], it states that decisions are not always optimal, it is the willingness to take risk that determine the way decisions are made, but [4] suggested that it is important not to place too much concentration on investors and their rationality only, but also to introduce a variable of irrationality into the prospect theory in order to show that it is not only the willingness to take risk that determines the way decisions are made, it could also be as a result of herding behaviour.

Herding behaviour is often used in literature to describe the co-movement of members in a group without a planned direction [5]. The mimicking tendency of investors termed as herding results in investors buying and selling same or similar stocks in large numbers over a period of time [6]. It is a way of imitating how the other person buys or sells shares and implementing that in one's portfolio in order to feel more secure. Most investors herd based on information, reputation or compensation (rational herding), while other investors imitate the action of others rather than trusting their own assessment of the situation. In other words, when investors herd, they show a willingness to downplay the importance of their own information and evaluation in favour of the aggregate market consensus [7].

Fluctuations in demand and supply of stocks are daily activities in the stock market. [8] defined market liquidity as the capacity of the market to absorb temporary fluctuations in demand and supply without undue dislocations in prices. He proposed that stock market liquidity can be measured as total turnover in relation to market capitalisation, that is, the turnover ratio. Bernstein 
(as cited in [9]) stated that stock market liquidity and market efficiency cannot work together because the more the liquidity in the market, the less efficient the market becomes. He explained that a liquid market, on arrival of new information, keeps the noise and sudden price changes minimal. On other hand, in efficient markets, prices move fast as the new information arrives. Knowing fully that an inefficient market where information is difficult to get may trigger herding behaviour of investors, therefore, how does the existence of market liquidity affect herding behaviour? This question has not been considered by numerous studies [4], therefore, it is necessary to investigate if liquidity in the market will have impact on herding behaviour.

\section{Theoretical and Empirical Review}

\subsection{Efficient Market Hypothesis}

In the stock market, an important principle used to measure the efficiency is the correlation between prices and all the information present in a market [10]. The efficient market was first used in a paper by [11] who stated that in an efficient market, the impact of new information on basic values will be seen immediately in security prices if there is competition. The efficient market hypothesis is linked to the notion of a random walk $[12,13]$. It is suggested that by using this information, there is no way to gain excess profit more than the market since the current stock prices reflect available information about the firm's value. EMH deals with one of the vital questions in the stock market which is why and how prices change in the stock markets and it also has important implications for investors as well as financial managers [14].

EMH is one of the well-known methods for measuring the future value of stock prices. [15] stated that according to the EMH, market prices should incorporate and reflect all available information at any point in time. Invariably, the market is said to be efficient if its prices are formulated based on all disposable information. A stock market is efficient only if all relevant information about the company is reflected in the stock price of the company. [15] affirmed [11] and [16] classification of efficient markets hypothesis into three types: weak form, semistrong form, and strong form efficiency.

\subsection{Capital Asset Pricing Model}

The capital asset pricing model (CAPM) was developed in mid-1960s by $[17,18,19]$. Consequently, the model is often referred to as Sharpe-Lintner-Mossin Capital Asset Pricing Model. CAPM was developed when the theoretical foundations of decision making under uncertainty were moderately new and empirical facts about return and risk in the stock markets were unknown [20]. [21] described the CAPM as one of the early risk management models which has remained a principal ornament for modelling modern financial economics. [22] described it as a useful tool for estimating the cost of capital for firms and the returns that investors require in investing in a company's assets. The CAPM explains the trade-off between assets' returns and their risks, measuring the risk of an asset as the covariance of its returns with returns on the overall market. It shows that the return on a security is equal to the risk-free return plus a risk premium, which is based on the beta of that security. It implies that not all risks should affect asset prices.

The model (CSAD) for detecting herding behaviour was derived by [23] from the conditional version of CAPM. [24] stated that according to the Capital Asset Pricing Model (CAPM), there is a linear relationship between return dispersion of individual company's stock and return on market portfolio, but when different market conditions exist, investors may react in a more uniform manner, exhibiting herding behaviour which brings about a non-linear market return.

\subsection{Empirical Review}

The existence and measure of herding in stock markets is distinguished on two categories of measuring herding based on the nature of the defined data. The basis for the first measures is investors' portfolio's composition and investors' transaction flow, while the second category focuses on herding as a whole and this indicates collective behaviour of all market participants.

[25] empirically examined the patterns of trading of institutional investors by concentrating on the frequency of herding and positive-feedback trading, which are related to the general notion that institutional investors disrupt stock prices. 769 all-equity tax-exempt funds which is predominantly pension funds were sampled and evaluated; these funds were managed by 341 institutional money managers in the United State. The result shows that there is a little evidence of herding among pension fund managers when trading in large stocks (those in the top two quintiles by market capitalization), which indicates over $95 \%$ concentration of their trading. Evidence of herding was found in smaller stocks, but the extent is far from dramatic. Also, the estimations of the study of [26] based on 60 mutual funds specialized in shares German declare that herding is a little higher than the ones gotten from other developed financial markets.

[27] made used of Cross-Sectional Standard Deviation (CSSD) which they derived to measure herding. Data on daily returns of stocks listed on the NYSE and Amex for July 1962 to December 1988 were used and the results show that herding occurs when the market is under stress, i.e. when an individual investor possibly ignore their own information and evaluation and go with the market consensus. [23] also made used of their derived technique which is the Cross-Sectional Absolute Deviation (CSAD) and studied markets in the U.S., Hong Kong, South Korea, Taiwan and Japan. They discovered that herding does not take place in the U.S. and Hong Kong, little trace of herding in Japan, but significant proof of herding in South Korea and Taiwan.

[24] used daily data of industrial stock returns to study herding behaviour of 18 countries which are United States, Australia, France, Germany, Hong Kong, Japan, the United Kingdom, Argentina, Brazil, Chile, Mexico, China, South Korea, Taiwan, Indonesia, Malaysia, Singapore, and Thailand for May 25, 1988 to April 24, 2009. Contrary to previous studies that evidence of herding was 
not seen in advanced markets $[23,28]$, they discovered significant evidences supporting the existence of herding in all the national markets except the US and Latin America. [29] concluded that Indian investors are better informed and behave rationally since there is no significant evidence of herding in Indian stock markets. In contrast to [27], they suggested that herding can be more pronounce before market stress, rather than during market stress since market crisis can lead to market equilibrium. Contrary to the results of [23] who discovered herding in emergent economies such as South Korea and Taiwan; [30] used daily data of fifty (50) from the period of April 2006 to March 2011 and did not find herding in the Indian stock market. Nevertheless, individual tests for bull and bear periods of the market show that herding is detected in larger degree in bull period. These findings are in support of the results of [31]. [32] examined herding in Dhaka Stock Exchange (DSE) in Bangladesh for a period of seven years. Daily and monthly returns for all stocks listed on the Dhaka Stock Exchange were used and there was no existence of herding in Dhaka Stock Exchange for the period studied.

\section{Methodology and Data Description}

\subsection{Foundation of Estimated Model}

The model for analysing herding behaviour during period of stock market liquidity was expanded from the work of [4] which is in line with the study made by [24]. The Cross-Sectional Absolute Deviation (CSAD) which measures returns dispersion was used to identify herding behaviour. The $\mathrm{CSAD}_{\mathrm{t}}$ is stated below:

$$
C S A D_{t}=\frac{1}{N} \sum_{i=1}^{N}\left|R_{i, t}-R_{m, t}\right|
$$

Where $\mathrm{R}_{\mathrm{i}, \mathrm{t}}$ is the observed stock return of industry $i$ at time $t, R_{m, t}$ is the cross-sectional average stock of $\mathrm{N}$ returns in the portfolio at time $\mathrm{t}$ and $\mathrm{N}$ is the number of firms in the portfolio.

\subsection{Herding Behaviour and Stock Market Liquidity}

This study expanded the work of [4] to determine herding behaviour during period of high and low stock market liquidity. Stock market liquidity is measured as total turnover in relation to market capitalisation, that is, the turnover ratio [8]. The potential effects of asymmetric herding behaviour in relation to stock market is measured by:

$$
\begin{aligned}
C S A D_{i, t}= & \gamma_{0}+\gamma_{1} D^{\text {Hliquidity }}\left|R_{m, t}\right|+\gamma_{2}\left(1-D^{\text {Hliquidity }}\right)\left|R_{m, t}\right| \\
& +\gamma_{3} D^{\text {Hliquidity }} R_{m, t}^{2}+\gamma_{4}\left(1-D^{\text {Hliquidity }}\right) R_{m, t}^{2}+\varepsilon
\end{aligned}
$$

Where $\mathrm{D}^{\text {Hliquidity }}$ is a dummy variable which takes the value 1 during the month of high liquidity and 0 otherwise. Market liquidity is assumed to be high if it exceeds the weighted average of the liquidities of six months preceding the study period and vice versa.

\subsection{Data}

To compare the existence of herding behaviour in Conglomerate and Consumer goods sectors, the study made used of 28 stocks' returns from the two sectors in the Nigerian stock exchange with a monthly frequency from January, 2001 to December, 2015. The criteria for choosing the 28 stocks from the total of 34 stocks listed in these sectors are the stocks that are consistently listed on the Nigerian stock exchange, companies that are still actively trading on the floor of the Nigerian stock exchange, those that traded most on the Nigerian stock market and they contributed greatly to the total market capitalization. The methodology stated above are applied on the group of stocks on the basis of sector classification in the Nigerian stock exchange. The monthly stock returns are determined by applying the formula $R_{i, t}=\frac{P_{i, t}-P_{0, t}}{P_{0, t}}$ respectively. $P_{i, t}$ represents the monthly closing prices of stock $i$ at time $t$ while $P_{0, t}$ represents the monthly opening prices of stock ${ }_{0}$ at time $t$. The returns of market portfolio are calculated based on equally weighted portfolio of all companies in each sector classification.

\section{Empirical Results}

\subsection{Descriptive Statistics}

Table 1 summarized the descriptive statistics respectively for average monthly market returns and dispersion returns of market portfolio. The average monthly returns of market portfolio for Consumer goods sector was 0.05 , while that of Conglomerate sector was 0.02. It indicated that Consumer goods sector had an average increase of $5 \%$ in returns compared to the $2 \%$ increase in Conglomerate sector. The average monthly returns volatility varies between 0.20 and 0.11 respectively for Consumer and Conglomerate sectors. This observation was in line with the theoretical assumption of investment which states that the higher the risk, the higher the returns.

The descriptive statistics of CSAD for the two sectors show mean values of 0.17 and 0.09 for Consumer goods and Conglomerate sector respectively. These results depicted that Consumer goods sector had the higher market variation across industrial returns compared to Conglomerate sector. The values of the standard deviation compared to the mean values of the two sectors showed 0.36 for Consumer goods and 0.08 for Conglomerate sector. It indicated that Consumer goods experienced a higher unusual variations compared to Conglomerate sector. This unusual variation could be due to unexpected news or shocks. This decision was reached based on the work of [24] which says that a higher mean value suggests significantly higher market variations across industrial returns for one industry compared to others, while a higher standard deviation suggests that the market had unusual cross-sectional variation due to unexpected news or shocks. 
Table 1. Descriptive Statistics of Average Monthly Returns of Sectors and Cross-Sectional Returns Dispersion

\begin{tabular}{|l|l|l|}
\hline \multicolumn{3}{|l|}{ Panel 1: Average Monthly Returns of Portfolio } \\
\hline Sectors/Descriptive Statistics & Consumer Goods & Conglomerate \\
\hline Mean & 0.05 & 0.02 \\
\hline Median & 0.02 & -0.01 \\
\hline Maximum & 1.81 & 1.02 \\
\hline Minimum & -0.19 & -0.14 \\
\hline Std. Dev. & 0.20 & 0.11 \\
\hline Skewness & 6.44 & 4.52 \\
\hline Kurtosis & 50.01 & 36.35 \\
\hline & & \\
\hline Jarque-Bera & 17817.73 & 8954.02 \\
\hline Probability & 0.00 & 0.00 \\
\hline & & \\
\hline Sum & 9.26 & 3.01 \\
\hline Sum Sq. Dev. & 7.17 & 2.30 \\
\hline & & \\
\hline Observations & 180 & 180 \\
\hline N & 28 & 28 \\
\hline Panel 2: CSAD & \\
\hline Mean & & \\
\hline Median & 0.17 & 0.09 \\
\hline Maximum & 0.10 & 0.07 \\
\hline Minimum & 3.53 & 0.54 \\
\hline Std. Dev. & 0.02 & 0.005 \\
\hline Skewness & 0.36 & 0.08 \\
\hline Kurtosis & 7.02 & 2.55 \\
\hline & 56.69 & 11.31 \\
\hline Jarque-Bera & & \\
\hline Probability & 23100.73 & 180.13 .14 \\
\hline & 0.00 & \\
\hline & & \\
\hline Sum & 30.39 & \\
\hline Sum Sq. Dev. & 23.75 & \\
\hline & & \\
\hline Observations & \multicolumn{2}{|l|}{} \\
\hline N & \multicolumn{2}{|l|}{} \\
\hline
\end{tabular}

\subsubsection{Graphical Presentation of Monthly Returns}

The movement of market returns of each sector is further examined graphically to show how the returns moved for the period of fifteen years. Figure 1 and Figure 2 below showed that there was a high rate of change in returns noticed by the two sectors between 2007 and 2008. This could be as a result of change of government in Nigeria which took place in May, 2007. A change of government may either increase or decrease the stock price since the expectations of investors will also change. Considering the rate of increase experienced at the early months of 2007, one can attribute it to positive expectation from the in-coming then government and its impact on the stock market. It could also be deduced from the graph that both sectors experienced a serious crash in returns between late 2008 and 2009. This observation could be traced to the global financial meltdown of 2007 - 2008. A comparative view of the two sectors together on Figure 3 showed that Consumer goods sector experienced a higher increase rate of returns compared to the Conglomerate sector. This indicated that due to the change of government, investors made more investments in Consumer goods compared to Conglomerate sector.
CON

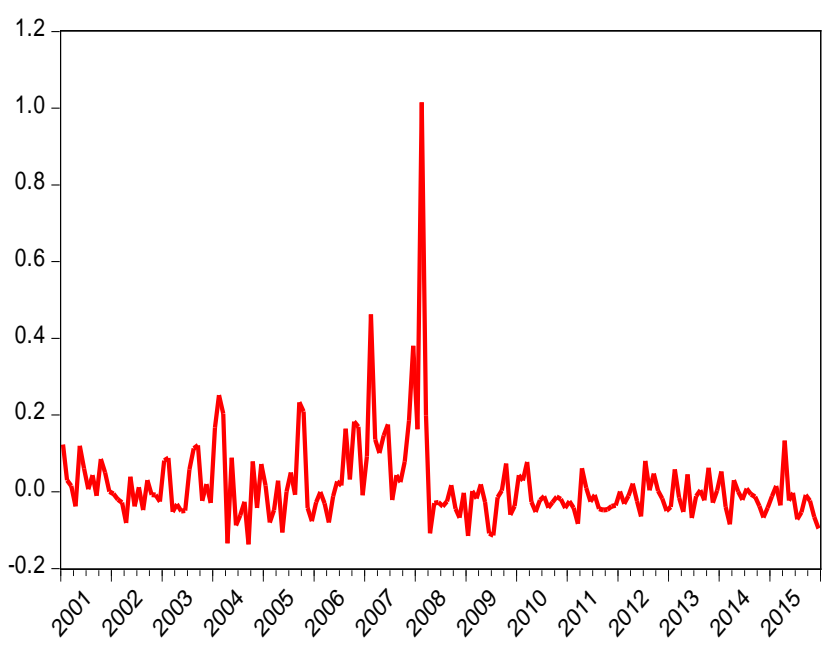

Figure 1. Monthly Movement of Conglomerate Market Returns

CG

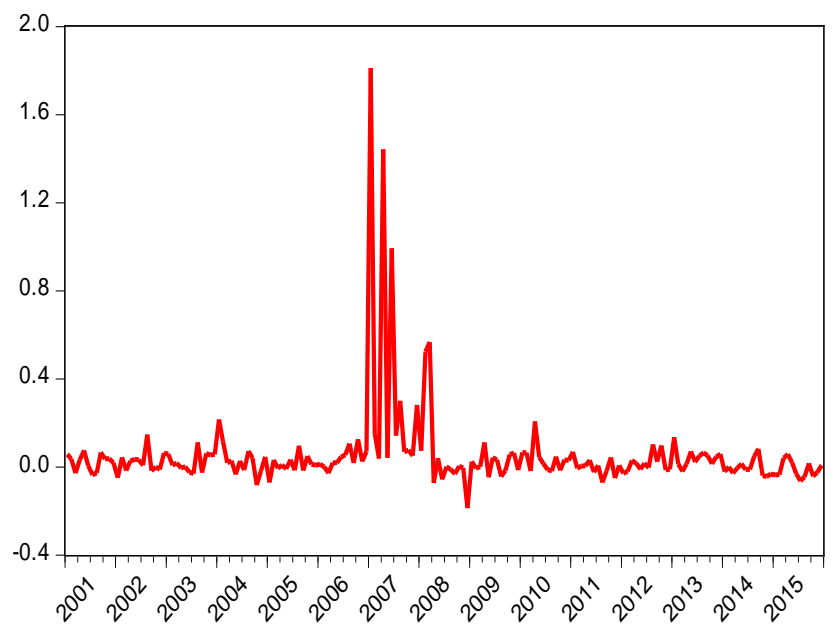

Figure 2. Monthly Movement of Consumer Goods Market Returns

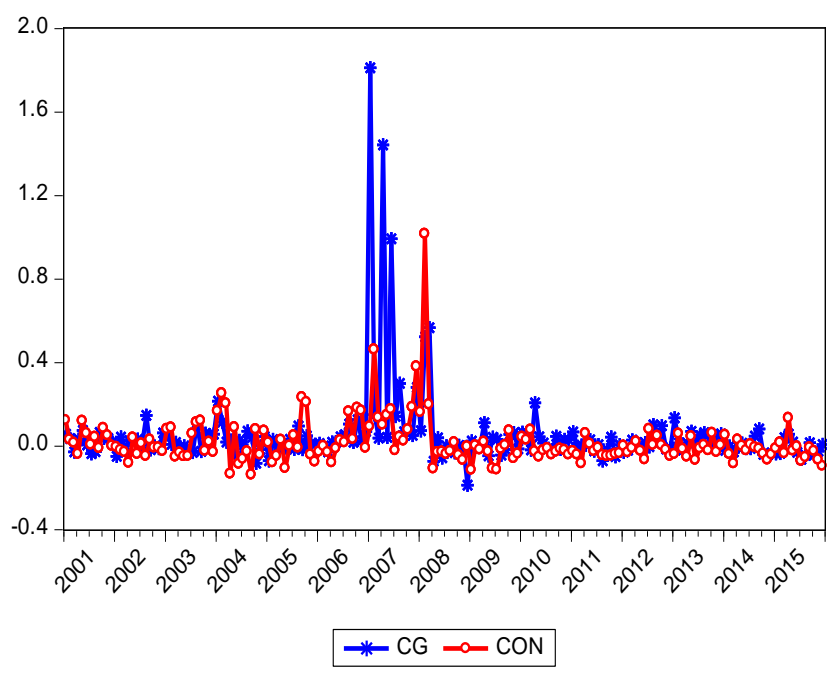

Figure 3. Comparative Monthly Movement of Market Returns of the two Sectors

\subsection{Test of Stationarity}

Table 2 and Table 3 below showed the ADF unit root test of market capitalization and turnover for the two 
sectors. The ADF statistics at level were -6.269, -8.907 and $-1.009,0.012$ for Consumer goods and Conglomerate sectors respectively, while the related critical values at $5 \%$ were -3.410 and -3.414 respectively. The absolute values of the observed ADF were greater than the absolute value of their corresponding critical value for market capitalization and turnover of Consumer goods, while it is contrary for Conglomerate sector. The result affirmed that the values of market capitalization and turnover of Consumer goods sector were stationary at level, while Conglomerate sector's variables were non-stationary. Since Conglomerate sector's variables were non-stationary at level, ADF was conducted I(1) and the results revealed an observed ADF statistics of -7.5650 and -10.027 . This implied the rejection of the null hypothesis of a unit root, and the evidence of integration at order 1 was valid for both variables of Conglomerate sector, which simply meant that at $1^{\text {st }}$ differential of the unit root test, market capitalisation and turnover of Conglomerate sector were stationary.

Table 2. ADF Unit Root Test Results of Market Capitalisation

\begin{tabular}{|c|c|c|c|c|}
\hline Variable & ADF-Stat & $\begin{array}{c}\mathbf{5 \%} \text { Critical } \\
\text { Value }\end{array}$ & P-Value & $\begin{array}{c}\text { Order of } \\
\text { Station. }\end{array}$ \\
\hline CG & -6.269 & -3.410 & 0.0000 & $1(0)$ \\
\hline CON & -1.009 & -3.414 & 0.9408 & $1(1)$ \\
\hline
\end{tabular}

Table 3. ADF Unit Root Test Results of Market Capitalisation

\begin{tabular}{|c|c|c|c|c|}
\hline Variable & ADF-Stat & $\begin{array}{c}\text { 5\% Critical } \\
\text { Value }\end{array}$ & P-Value & $\begin{array}{c}\text { Order of } \\
\text { Station }\end{array}$ \\
\hline CG & -8.907 & -3.410 & 0.0000 & $1(0)$ \\
\hline CON & 0.012 & -3.414 & 0.9964 & $1(1)$ \\
\hline
\end{tabular}

\subsection{Regression Results}

Table 4 showed the results of the effects of stock market liquidity on herding behaviour for both sectors. During high and low liquidity, only Conglomerate sector with coefficient values of -0.6269 and -0.4742 showed evidence of herding behaviour which is not statistically significant, while there was no evidence of herding behaviour in Consumer goods sector. The existence of herding was seen when the coefficients attached to the non-linear market return $\left(\mathrm{R}_{\mathrm{m}, \mathrm{t}}^{2}\right)$ showed a negative sign [4]; the coefficients of $\mathrm{D}^{\text {Hliquidity }} \mathrm{R}_{\mathrm{m}, \mathrm{t}}^{2}$ showed the existence of herding during high volatility while $\left(1-\mathrm{D}^{\text {Hliquidity }}\right) \mathrm{R}_{\mathrm{m}, \mathrm{t}}^{2}$ showed the existence of herding during low volatility. The p-value revealed that at 0.01 level of significance, the null hypothesis was rejected, therefore, there is impact of stock market liquidity on herding behaviour in both sectors. These results implied that the impact of stock market liquidity on herding behaviour does not determine the existence of significant level of herding behaviour in both sectors.

Table 4. Estimates of Herding Behaviour in Period of Stock Market Liquidity

\begin{tabular}{|c|c|c|c|c|c|}
\hline Sect. & Cons. & $\begin{array}{c}\mathbf{D}^{\text {Hliquidity }} \\
\left|\mathbf{R}_{\mathbf{m}, \mathbf{t}}\right|\end{array}$ & $\begin{array}{c}\left(\mathbf{1}-\mathbf{D}^{\text {Hliquidity }}\right. \\
\left|\mathbf{R}_{\mathbf{m}, \mathbf{t}}\right|\end{array}$ & $\begin{array}{c}\mathbf{D}^{\text {Hliquidity }} \\
\mathbf{R}_{\mathbf{m}, \mathbf{t}}^{2}\end{array}$ & $\begin{array}{c}\left(\mathbf{1}-\mathbf{D}^{\text {Hliquidity }}\right. \\
\mathbf{R}_{\mathbf{m}, \mathbf{t}}\end{array}$ \\
\hline \multirow{2}{*}{ CON } & 0.0302 & $1.1366^{* * *}$ & $1.0013^{* * *}$ & $-0.6269^{* * *}$ & $-0.4742^{* * *}$ \\
& $(0.0000)$ & $(0.0000)$ & $(0.0000)$ & $(0.0000)$ & $(0.0000)$ \\
\hline \multirow{2}{*}{ CG } & 0.0495 & $1.6279^{* * *}$ & $1.4778^{* * *}$ & $0.1591^{* * *}$ & $0.2521^{* * *}$ \\
& $(0.0000)$ & $(0.0000)$ & $(0.0000)$ & $(0.0000)$ & $(0.0000)$ \\
\hline
\end{tabular}

${ }^{* * *}$, level of significance at $1 \%$

The values in the parentheses () are p-value

\section{Conclusion}

The purpose of this paper was to comparatively study the impact of stock market liquidity on herding behaviour between Conglomerate and Consumer goods sectors for a period of 15 years in Nigerian stock market. In considering the impact, the existence of herding behaviour in the sectors was also looked into. For both sectors identified, the study showed empirical evidences in support of the existence of herding behaviour that is not statistically significant during stock market liquidity in Conglomerate sector, while evidence of herding behaviour was not noticed in Consumer goods sector. The study also revealed that stock market liquidity had effect on herding behaviour in both sectors, but the impact did not determine significant level of herding behaviour. The study recommended that market participants should rely more on their own decisions so that herding behaviour will not be noticed since market liquidity does not cause disruptions in prices and Nigerian stock exchange should make all information available to all market participants in order to boost their confidence in making investment decisions.

\section{Acknowledgements}

This is to appreciate Prof. J.S. Kehinde for his motivations in carrying out this study. I also want to appreciate Prof. J.O. Adewoye for giving us the fatherly support in carrying out this investigation. Thank you and God bless you.

\section{References}

[1] Yadav, S. (2017). Stock market volatility: a study of Indian stock market. Global Journal for Research Analysis, 6(4): 629-632.

[2] Ohiomu, S. \& Enabulu, G. O. (2011). The effect of stock market on economic growth in Nigeria. Journal of Research in National Development, 9(1): 287-295.

[3] Kahneman, D. \& Tversky, A. (1979). Prospect theory: an analysis of decision under risk. Econometrica, 47(2): 263-292.

[4] Ouarda, M., Abdelfatteh, E. B. \& Olivero, B. (2013). Herding behaviour under markets condition: Empirical evidence on the European financial markets. International Journal of Economics and Financial Issues, 3(1): 214-228.

[5] Kim, C., Lee W., Choi, Y.H. \& Ahn, J.Y. (2013). Analyzing herd behaviour in global stock markets: An intercontinental comparison. Retrieved February 23, 2015 from

http://arxiv.org/pdf/1308.3966.pdf

[6] Ganesh, R. \& Naresh, G. (2016). Industry herding behaviour in India stock market. American Journal of Finance and Accounting, 4(3-4): 284-308.

[7] Tran, N. M. \& Huy, H. T. (2011). Herding behaviour in an emerging stock market: empirical evidence from Vietnam. Research Journal of Business Management, 5(2): 51-76.

[8] Datar, M. K. (2000). Stock market liquidity: measurement and implications. Fourth Capital Market Conference, India.

[9] Kumar, G. \& Misra, A.K. (2015). Closer view at the stock market liquidity: A literature review. Asian Journal of Finance \& Accounting, 7(2): 35-57.

[10] Rossi, M. (2018). Efficient market hypothesis and stock market anomalies: empirical evidence in four European countries. The Journal of Applied Business Research, 34(1): 183-192.

[11] Fama, E. F. (1965). The behaviour of stock market prices. Journal of Business, 38(1): 34-105. 
[12] Malkiel, B. G. (2009). The price is usually right, a random walk down Wall Street, 19 ${ }^{\text {th }}$ Edition. Retrieved on February 10, 2015 from http://www.relooney.fatcow.com.

[13] Kofarbai, H. Z. \& Zubairu, M. (2016). Efficient Market Hypothesis in Emerging Market: a Conceptual Analysis. European Scientific Journal, 12(25): 260-270.

[14] Ball, R. (1995). The theory of stock market efficiency: Accomplishment and limitations. Journal of Applied Corporate Finance, 8(1): 4-18.

[15] Rossi, M. (2015). The efficient market hypothesis and calendar anomalies: a literature review. Int. J. Managerial and Financial Accounting, 7(3-4): 285-296.

[16] Fama, E. F. (1970). Efficient capital markets: A review of theory and empirical work. Journal of Finance, 25(2): 383-417.

[17] Sharpe, W. F. (1964). Capital asset prices: a theory of market equilibrium under conditions of risk. Journal of Finance, 19(3): 425-442.

[18] Lintner, J. (1965). The valuation of risk assets and the selection of risky investments in stock portfolios and capital budgets. The Review of Economics and Statistics, 47(1): 13-37.

[19] Mossin, J. (1966). Equilibrium in a capital asset market. Econometrica, 34(2): 768-783.

[20] Perold, A. F. (2004). The capital asset pricing model. Journal of Economic Perspectives, 18(3): 3-24.

[21] Oseni, E. \& Olanrewaju. R.O. (2017). A capital asset pricing model's (CAPM's) beta estimation in the presence of normality and non-normality assumptions. International Journal of Finance and Banking Research. 3(3): 44-52.

[22] Rossi, M. (2016). The capital asset pricing model: a critical literature review. Global Business and Economics Review, 18(5): 604-617.
[23] Chang, E.C., Cheng, J.W. \& Khorana, A. (2000). An examination of herd behaviour in equity markets: An international perspective. Journal of Banking and Finance, 24(10): 1651-1679.

[24] Chiang, T. C. \& Zheng, D. (2010). An empirical analysis of herd behaviour in global stock markets. Journal of Banking \& Finance, 34(8): 1911-1921.

[25] Lakonishok, J., Shleifer, A. \& Vishny, R.W. (1992). The impact of institutional trading on stock prices. Journal of Financial Economics, 32(1): 23-43.

[26] Walter, A. \& Weber, F.M. (2006). Herding in the German mutual fund industry. European Financial Management, 12(3): 375-406.

[27] Christie, W.G. \& Huang, R. D. (1995). Following pied piper: do individual returns herd around the market? Financial Analysts Journal, 51(4): 31-37.

[28] Demirer, R. \& Kutan, A. (2006). Does herding behaviour exist in Chinese stock markets? Journal of International Financial Markets, Institutions and Money, 16(2): 123-142.

[29] Lakshman, M. V., Basu S. \& Vaidyanathan, R. (2011). Market wide herding and the impact of institutional investors in the Indian capital market. Indian Institute of Management, Bangalore Working Paper 327.

[30] Prosad, J., Kapoor, S. \& Sengupta, J. (2012). An examination of herd behaviour: an empirical study on Indian equity market. International Conference on Economics and Finance Research, 32: 11-15.

[31] Lao, P. \& Singh, H. (2011). Herding behaviour in the Chinese and Indian stock markets. Journal of Asian Economics, 22(6): 495-528.

[32] Ahsan, A. F. M. \& Sarkar, A. H. (2013). Herding in Dhaka stock exchange. Journal of Applied Business and Economics, 14(2): 11-19. 